\title{
Variations in Carotenoids, Fat-Soluble Micronutrients, and Color in Cows' Plasma and Milk Following Changes in Forage and Feeding Level
}

\author{
P. Nozière, ${ }^{\star 1}$ P. Grolier,† D. Durand, ${ }^{\star}$ A. Ferlay, ${ }^{\star}$ P. Pradel,‡ and B. Martin* \\ *Unité de Recherche sur les Herbivores, and \\ †Unité des Maladies Métaboliques et Micronutriments, INRA Theix, 63122 Saint Genès Champanelle, France \\ ‡Domaine de la Borie, INRA Marcenat, 15190 Marcenat, France
}

\begin{abstract}
The main aim of this work was to assess factors affecting the secretion of carotenoids in cows' milk. Our objectives were 1) to determine the kinetics of the decrease in carotenoids in plasma, milk, and adipose tissues following a switch from a high- to a low- carotenoid diet; and 2) to specify whether, during lipomobilization, the restitution of these compounds stored in the adipose tissues is sufficient to modify their secretion in milk. During the preexperimental period, 32 cows in midlactation were fed a grass silage-based diet, and were then assigned to 4 groups; 2 groups were maintained on the grass silage diet and 2 were switched to a late hay diet. For each forage diet, one group was fed according to net energy for lactation and nitrogen requirements, and the other was submitted to an energetic underfeeding, with similar forage and carotenoid intake between groups. Variations in concentration of carotenoids and color index (CI) of plasma and milk were monitored over $8 \mathrm{wk}$. Other components of nutritional interest; i.e., vitamin $\mathrm{E}(\mathrm{VE})$, vitamin $\mathrm{A}$, and fatty acids, were also measured. The switch from grass silage to hay diet induced a rapid decrease in concentration of $\beta$-carotene (BC) and VE and in the CI of plasma and milk during the first 2 wk. Pools of BC in adipose tissues also decreased by $40 \%$. Concentrations of BC at the end of the experiment for silage and hay groups were 5.10 and $1.71 \mu \mathrm{g} / \mathrm{mL}$ in plasma and 0.17 and $0.07 \mu \mathrm{g} / \mathrm{mL}$ in milk, respectively. The energetic underfeeding did not affect $\mathrm{BC}$ concentration in plasma and induced a small increase in milk BC concentration, related to a decreased milk yield. In the silage group, the energetic underfeeding after 3 to 4 wk induced a decrease in CI and VE of plasma, but not of milk. The fatty acid profile in milk was modified by the change from grass silage to hay $\operatorname{diet}(\mathrm{C} 10$ to $\mathrm{C} 14$ and linoleic acid increased; stearic and
\end{abstract}

Received October 5, 2005.

Accepted January 19, 2006.

${ }^{1}$ Corresponding author: noziere@clermont.inra.fr linolenic acid percentages decreased) and by underfeeding (oleic, vaccenic, and rumenic acid percentages increased). This study shows that BC and VE levels persist in midlactation cows' plasma and milk for about 2 wk. The results could not confirm a release of $\mathrm{BC}$ by bovine adipose tissue, but the level of underfeeding was moderate in this trial. The concentration of $\mathrm{BC}$ explained 58 and $40 \%$ of variation in CI of plasma and milk, respectively. These CI appear to be valuable tools for diet traceability (i.e., silage vs. hay).

Key words: carotenoid, vitamin E, feeding level, dairy cow

\section{INTRODUCTION}

The nature of the diet ingested by dairy cows strongly influences the content and composition of milk fat (Chilliard et al., 2001) and the fat-soluble micronutrient fraction of dairy products, in particular $\beta$-carotene (BC), vitamins A (VA), and E (VE) (Martin et al., 2004). Animal diet thus appears to be an effective means of modifying the concentration of some micronutrients and fatty acids (FA) that are of nutritional or sensorial interest in dairy products. Furthermore, animal diet is increasingly considered by the consumer as an important criterion in judging product quality. In particular, grass-based diets enjoy a positive image that should be objectively confirmed and quantified. Fatty acids, carotenoids, and fat-soluble vitamins in dairy products have been recognized as potential tracers of animal feeding management (Martin et al., 2005). A simple method based on quantifying the signature of carotenoid pigments in herbivore tissues or products has been developed as a tool to trace grass feeding in ruminants (Prache et al., 2002). In dairy cows, the carotenoid content in milk and plasma is known to vary according to breed, parity, physiological stage, production level, and sanitary state, but type of forage is the main factor affecting BC in plasma and milk. Grass-based diets, especially pasture, lead to a higher milk BC concentration than diets rich in concentrates or corn silage (Havemose et al., 2004; Martin et al., 2004). The majority 
of published results concerning the effect of diet on carotenoid concentrations in plasma and milk were obtained from animals with positive energy balance after several weeks of adaptation to the diet. The kinetics of carotenoid concentrations during a change in diet is not known. Also unknown is whether these lipophilic components, which are stored in the adipose tissues of the animal, are released when the animals are energy depleted and mobilize their body reserves. The objectives of this trial were 1) to determine the kinetics of the decrease in carotenoids in plasma, milk, and adipose tissues following a switch from a high- to a low-carotenoid diet; and 2) to determine whether, during lipid mobilization, the release of the adipose stores of these compounds is sufficient to modify their concentrations in milk. Kinetics of color index (CI) and VE in plasma and milk were also measured, together with changes in plasma and milk VA and milk FA.

\section{MATERIALS AND METHODS}

\section{Animals, Treatments, and Experimental Design}

The experiment was conducted on the experimental farm at Marcenat (1,100 m above sea level, Cantal, France) on 40 midlactation, multiparous Montbeliarde and Holstein dairy cows. The cows were fed pasture until the end of September, at which time they were housed inside and fed a grass silage-based diet $(1.7 \mathrm{~kg}$ of DM/d; hay per cow and grass silage ad libitum) until the beginning of the experiment. Parturition took place on average at the end of November.

Thirty-two cows were assigned to 4 homogeneous groups according to breed (5 Montbeliardes and 3 Holsteins/group), BW (654 $\pm 52 \mathrm{~kg}$ ), DIM (102 $\pm 17 \mathrm{~d})$, milk production $(25.3 \pm 4.6 \mathrm{~kg})$, total plasma carotenoids $(4.7$ $\pm 1.2 \mu \mathrm{g} / \mathrm{mL}$ ), and total milk carotenoids $(107 \pm 44 \mathrm{ng} /$ $\mathrm{mL}$ ). The experimental period began on March 10 (d 0 ). Throughout the experimental period ( $8 \mathrm{wk}$ ), 2 groups were fed a hay-based diet (low in carotenoids) and the other 2 groups were fed a grass silage-based diet (high in carotenoids). Grass silage was the same for both preexperimental and experimental periods. It was prepared from a first cut of perennial ryegrass on June 13. Silage was prepared from June 15 to 17 with one day's rain. Two silos were used successively, with change in silo at d 19. Hay was taken from a natural mountain grassland cut on June 22 after being grazed between May 2 and 7. Hay was field-dried and harvested on June 25. Nutritive value and intake of feeds are presented in Table 1. Although probably underestimated due to an inadequate conservation of forage samples before analysis, BC concentrations were 3 -fold higher in grass silage than in hay (31 vs. $11 \mu \mathrm{g} / \mathrm{g}$ of $\mathrm{DM}$ ), and $\mathrm{BC}$ was not detected in concentrates. For each diet, the daily
Table 1. Composition and nutritive value of feeds, and intake

\begin{tabular}{|c|c|c|c|c|}
\hline & Hay & $\begin{array}{l}\text { Grass } \\
\text { silage }\end{array}$ & Barley & $\begin{array}{l}\text { Soybean } \\
\text { meal }\end{array}$ \\
\hline $\mathrm{OM}^{1}(\mathrm{~g} / \mathrm{kg}$ of $\mathrm{DM})$ & 933 & 902 & 974 & 927 \\
\hline $\mathrm{CP}^{2}(\mathrm{~g} / \mathrm{kg}$ of $\mathrm{DM})$ & 87 & 117 & 121 & 520 \\
\hline Crude fiber ${ }^{3}(\mathrm{~g} / \mathrm{kg}$ of $\mathrm{DM})$ & 319 & 304 & 50 & 70 \\
\hline OM digestibility ${ }^{4}(\%)$ & 58.3 & 71.2 & 86.0 & 90.0 \\
\hline Net energy $^{5}(\mathrm{Mcal} / \mathrm{kg}$ of DM$)$ & 1.14 & 1.45 & 1.97 & 1.99 \\
\hline $\mathrm{PDIN}^{5,6}(\mathrm{~g} / \mathrm{kg}$ of DM $)$ & 54 & 70 & 79 & 421 \\
\hline $\mathrm{PDIE}^{5,7}(\mathrm{~g} / \mathrm{kg}$ of DM) & 70 & 70 & 102 & 382 \\
\hline \multicolumn{5}{|l|}{ Intake $^{8}(\mathrm{~kg} \mathrm{DM} / \mathrm{d})$} \\
\hline Hay $\mathrm{HIGH}^{9}$ & 10.5 & 0 & 8.6 & 0.7 \\
\hline Hay LOW ${ }^{10}$ & 10.7 & 0 & 4.4 & 1.7 \\
\hline Grass silage High & 0 & 11.6 & 4.7 & 0.6 \\
\hline Grass silage Low & 0 & 11.4 & 0 & 1.5 \\
\hline
\end{tabular}

${ }^{1} \mathrm{OM}$ was determined by drying at $550^{\circ} \mathrm{C}$ for $6 \mathrm{~h}$.

${ }^{2} \mathrm{CP}$ was determined by the Kjeldahl method (AOAC, 1990).

${ }^{3}$ Crude fiber was determined according to Van Soest et al. (1991).

${ }^{4} \mathrm{OM}$ digestibility of forages was measured on sheep.

${ }^{5}$ Values were calculated according to equations from INRA (1989) and $\mathrm{OM}$ digestibility.

${ }^{6} \mathrm{PDIN}=$ Proteins digestible in the intestine, when the degraded $\mathrm{N}$ is limiting.

${ }^{7} \mathrm{PDIE}=$ Proteins digestible in the intestine, when the energy is limiting.

${ }^{8}$ Cows from hay-based diets received in addition $0.10 \mathrm{~kg}$ of DM/d of urea and all the cows received $0.18 \mathrm{~kg}$ of DM/d of a mineral-vitamin $\operatorname{mix}(4.5 \% \mathrm{P}, 20 \% \mathrm{Ca}, 4.5 \% \mathrm{Mg}, 5 \% \mathrm{Na}, 1,300 \mathrm{mg} / \mathrm{kg} \mathrm{Cu}, 6,000 \mathrm{mg} /$ $\mathrm{kg} \mathrm{Zn,} \mathrm{3,500} \mathrm{mg/kg} \mathrm{Mn,} 80$ mg/kg I, $32 \mathrm{mg} / \mathrm{kg} \mathrm{Co}, 20 \mathrm{mg} / \mathrm{kg}$ Se, 600,000 $\mathrm{UI} / \mathrm{kg}$ vitamin $\mathrm{A}, 120,000 \mathrm{UI} / \mathrm{kg}$ vitamin $\mathrm{D}_{3}, 1,300 \mathrm{UI} / \mathrm{kg}$ vitamin $\mathrm{E}$ ).

${ }^{9} \mathrm{HIGH}=$ Diet fed to $\mathrm{NE}_{\mathrm{L}}$ and nitrogen requirements according to the INRA (1989).

${ }^{10} \mathrm{LOW}=$ Diet energetically underfed by reducing the amount of concentrate (-6.2 Mcal of $\left.\mathrm{NE}_{\mathrm{L}} / \mathrm{d}\right)$.

amount of forage was limited (10.6 kg of DM hay, 11.5 $\mathrm{kg}$ of DM grass silage) at similar levels between the 2 groups and remained constant over the experimental period to provide the same amount of $\mathrm{BC}$ between groups. For each diet, animals were divided into 2 groups: in one group (high), animals were individually fed to $\mathrm{NE}_{\mathrm{L}}$ and nitrogen requirements according to the INRA (1989); animals in the second group (low) were individually submitted to energetic underfeeding by reducing the amount of concentrate $\left(-6.2 \mathrm{Mcal} \mathrm{NE}_{\mathrm{L}} / \mathrm{d}\right)$. Each animal received $180 \mathrm{~g} / \mathrm{d}$ of a mineral supplement to meet vitamins $\mathrm{A}, \mathrm{D}_{3}$, and $\mathrm{E}$ requirements.

There were 8 extra cows of Montbeliarde breed. Four cows were slaughtered on d 4 (control cows), whereas 2 cows were assigned to the hay high group, and 2 to the hay low group. These cows, together with 2 additional Montbeliarde cows from each of these experimental groups, were slaughtered using a captive bolt gun. The 4 hay high cows were slaughtered on d 36 and the 4 hay low cows on d 47. Slaughtered animals were used for subsequent determination of carotenoid distribution among adipose tissues. 
This study was carried out in accordance with French recommendations and with the guidelines of the Animal Care and Use Committee of the Institut National de la Recherche Agronomique (INRA) on the use of experimental animals, including animal welfare and appropriate conditions.

\section{Measurements and Sampling}

Intake was recorded individually on $4 \mathrm{~d} / \mathrm{wk}$. The amount of refusals was recorded daily. The DM $\left(103^{\circ} \mathrm{C}\right.$ for $24 \mathrm{~h}$ ) of feed was determined twice a week. Orts were weighed 4 times a week and their DM content was determined each time. A representative sample of each feed (one per silo for grass silage) was kept in the dark and stored at $-15^{\circ} \mathrm{C}$ under vacuum pending carotenoid and fatty acid determinations.

Cows were milked twice daily at 0600 and $1800 \mathrm{~h}$ and individual milk yields were recorded. Individual samples of milk (morning and evening) were taken $5 \mathrm{~d}$ before $(\mathrm{d}-5)$ and $1,2,3,4,5,8,10,12,15,18,23,29$, 36,43 , and $50 \mathrm{~d}$ after (d 1 to 50 ) the beginning of the experimental period (March 10). Samples were kept out of light. Milk fat and protein contents were determined (AOAC, 1990) by the infrared method (Milkoscan 4000, Foss System, Hillerød, Denmark). Color was assessed immediately on fresh milk from morning samples using a spectrocolorimeter (Minolta CM 2002, Minolta, Carrières sur Seine, France) on the bottom of an optical glass (5 cm diameter) containing $20 \mathrm{~mL}$ of milk. A CI was calculated as the upper area of the reflectance spectrum between 450 and $530 \mathrm{~nm}$ (10-nm steps), translated to make reflectance at $530 \mathrm{~nm}$ equal to zero. Results were also expressed in the Hunter L, a, b system, where "L" defines the position of the sample on the dark-light axis, "a" on the green-red axis, and "b" on the blueyellow axis following a tristimulus color measurement. Milk (morning samples) was frozen and stored at $-15^{\circ} \mathrm{C}$ until carotenoid and VE (all samples), VA, and fatty acid ( $\mathrm{d}-5$ and $\mathrm{d} 50)$ analysis.

Blood was withdrawn from the caudal vein $5 \mathrm{~d}$ before and $1,3,5,8,15,23,29,36,43$, and $50 \mathrm{~d}$ after the beginning of the experimental period using Li-heparin as anticoagulant. Samples were kept out of light. Blood was centrifuged $(300 \times g, 15 \mathrm{~min})$ for plasma preparation. Absorbance between 450 and $530 \mathrm{~nm}$ (10-nm steps) was immediately determined on plasma samples using a spectrophotometer (SmartSpect 3000, BioRad, Marnes la Coquette, France), and a CI was calculated as the area under the absorbance spectra. Plasma was frozen and stored at $-15^{\circ} \mathrm{C}$ until carotenoid and VE (all samples), and VA (d -5 and d 50) analysis. Plasma NEFA, glucose, urea, and BHBA (d -5 and $d 50$ ) were determined according to Ferlay and Chilliard (1999).
Adipose tissues were taken on slaughtered animals from subcutaneous caudal, intermuscular, internal, and kidney tissues. Samples were kept out of light and frozen at $-15^{\circ} \mathrm{C}$ until carotenoid analysis. Carcass fat was estimated from carcass weight and dissection of the sixth rib according to Robelin and Geay (1975) with a relative standard deviation of $6.2 \mathrm{~kg}$. Subcutaneous, intermuscular, and internal (pelvic and channel) fat were estimated from carcass fat with slopes of 0.26 , 0.56 , and 0.18 , respectively, as measured by Robelin et al. (1990) in mature dry Holstein cows. Kidney and offals fat were weighed. Total fat depots were determined by summation of carcass and offals fat depots.

\section{Carotenoid and Vitamin A Determination}

All extractions were performed at room temperature under yellow light. Plasma carotenoids and retinol were extracted with hexane and analyzed by HPLC using the technique described by Lyan et al. (2001), with echinenone and retinyl laurate as internal standards.

For milk analyses, $1 \mathrm{~mL}$ of milk was mixed with 1 $\mathrm{mL}$ of ethanol containing echinenone (internal standard) and $1 \mathrm{~mL}$ of hexane. Samples were then centrifuged $(1,200 \times g, 2 \mathrm{~min})$ and the upper organic phase was collected. This step was repeated once. The ethanolic layer was gently evaporated to dryness under pure $\mathrm{N}_{2}$. To the combined organic extracts, $1 \mathrm{~mL}$ of ethanol and water $(90 / 10, \mathrm{vol} / \mathrm{vol})$ was added. Tubes were mixed (5 min) and centrifuged $(1,200 \times g, 2 \mathrm{~min})$. The hexane phase was evaporated to dryness under pure $\mathrm{N}_{2}$. After adding $2 \mathrm{~mL}$ of $10 \% \mathrm{KOH}$ to the residue, the mixture was vortexed for $1 \mathrm{~min}$, and incubated at $37^{\circ} \mathrm{C}$ for 120 min. Saponification was stopped by addition of $1 \mathrm{~mL}$ of water. Carotenoids and retinol were then extracted twice with $1 \mathrm{~mL}$ of hexane. The organic phases were washed twice with $1 \mathrm{~mL}$ of water, collected, and finally added to tubes containing the dry residue of the initial ethanolic phase. Mixtures were vortexed, centrifuged, and evaporated to dryness under $\mathrm{N}_{2}$. The residues were dissolved in $200 \mu \mathrm{L}$ of dichloromethane and acetonitrile $(50 / 50, \mathrm{vol} / \mathrm{vol})$ and $80 \mu \mathrm{L}$ was injected for HPLC analysis.

For adipose tissue analysis, $80 \mathrm{mg}$ of adipose tissue was homogenized using a polytron apparatus (Bioblock Scientific, Illkirch, France) in $3 \mathrm{~mL}$ of chloroform and methanol $(2 / 1, \mathrm{vol} / \mathrm{vol})$ containing echinenone at $4^{\circ} \mathrm{C}$. After adding $2 \mathrm{~mL}$ of $100 \mathrm{~m} M$ phosphate buffer, the mixture was vortexed and centrifuged $(1,500 \times g, 10$ $\mathrm{min})$. The lower organic layer was collected and evaporated to dryness under $\mathrm{N}_{2}$. Then, $1 \mathrm{~mL}$ of $5.5 \% \mathrm{KOH}$ (wt/vol) and $0.1 \mathrm{~mL}$ of $12 \%$ pyrogallol (wt/vol) were added to the residues. Tubes were incubated at $37^{\circ} \mathrm{C}$ for $90 \mathrm{~min}$. Saponification was stopped by adding $1 \mathrm{~mL}$ 
of water, and then $3 \mathrm{~mL}$ of ethylic ether and hexane $(2 / 1, \mathrm{vol} / \mathrm{vol})$ were added and tubes were vortexed and centrifuged $(1,500 \times g, 10 \mathrm{~min})$. The organic phase was collected and washed twice with $1 \mathrm{~mL}$ of water and 1 $\mathrm{mL}$ of ethanol. After centrifugation, the organic layer was collected and evaporated to dryness. The residue was dissolved in $200 \mu \mathrm{L}$ of dichloromethane and acetonitrile $(50 / 50, \mathrm{vol} / \mathrm{vol})$ before HPLC analysis.

The HPLC apparatus consisted of a Waters system (Waters SA, Saint Quentin-en-Yvelines, France) equipped with a pump (Waters 610 fluid unit), a regulator (Waters 600 controller), a cooled auto-sampler (Waters 717 plus), and photodiode-array detectors (monitoring between 280 and $600 \mathrm{~nm}$, Waters 996). Millennium 32 software (version 3.05.01) from Waters was used for instrument control, data acquisition, and data processing. Carotenoids and VA were detected at 450 and $325 \mathrm{~nm}$, respectively, and identified by comparison of their retention time and spectral analysis with those of pure standard ( $>95 \%)$. Concentrations of carotenoids and VA were calculated by using an external standard curve and were then adjusted by percentage recovery of the added internal standards.

\section{Vitamin E Determination}

Plasma $\alpha$-tocopherol concentration was determined using the HPLC method adapted to bovine plasma described by Scislowski et al. (2005). Briefly, extraction of $\alpha$-tocopherol from plasma (500 $\mu \mathrm{L}$ ) was performed in $350 \mu \mathrm{L}$ of ethanol and $1 \mathrm{~mL}$ of hexane under agitation for $10 \mathrm{~min}$. Both $\alpha$-tocopherol and the internal standard (tocopherol acetate; $150 \mu \mathrm{L}$ of a $60 \mu \mathrm{g} / \mathrm{mL}$ ethanol solution) contained in the hexane phase were extracted by centrifugation $(10 \mathrm{~min}$ at $710 \times \mathrm{g})$. A second extraction with $1 \mathrm{~mL}$ of hexane was subsequently performed. The hexane phase was evaporated under a stream of $\mathrm{N}_{2}$ and redissolved in $150 \mu \mathrm{L}$ of methanol and dichloromethane (65/35, vol/vol). Conditions of separation for $\alpha$-tocopherol in the HPLC system (Kontron Analysis Division, Zurich, Switzerland) were as follows: an aliquot of 60 $\mu \mathrm{L}$ was injected on the HPLC column (nucleosil $5 \mu \mathrm{m}$ C18, $250 \times 4.6 \mathrm{~mm}$, Interchim, Montluçon, France), with the methanol mobile phase delivered at a flow rate of 2 $\mathrm{mL} / \mathrm{min}$ by the model 325 HPLC pump system (Kontron Analysis Division). The column effluent was monitored by UV spectrophotometry at $292 \mathrm{~nm}$ using a model 430 HPLC detector (Kontron Analysis Division). Chromatographic signals were analyzed using Kroma System 2000 software (Kontron Analysis Division).

Concentration of $\alpha$-tocopherol in milk was determined using the HPLC method described by Katsanidis and Addis (1999) and adapted to bovine milk in our laboratory. Combined in a test tube were $2 \mathrm{~mL}$ of milk, ascorbic acid (500 mg), $14.6 \mathrm{~mL}$ of saponification solution $[11 \% \mathrm{KOH}$ (wt/vol), $55 \%$ ethanol (vol/vol), and $45 \%$ deionized water ( $\mathrm{vol} / \mathrm{vol}$ ) plus $0.4 \mathrm{~mL}$ of internal standard: $2.25 \% \alpha$-tocotrienol (wt/vol); $97.75 \%$ ethanol (vol/ vol)]. The tubes were then placed in a shaking water bath for $20 \mathrm{~min}$ at $80^{\circ} \mathrm{C}$. After cooling in an ice water bath for $10 \mathrm{~min}$, the VE was extracted using a hexane and water mixture $(2 / 1, \mathrm{vol} / \mathrm{vol})$. The hexane fraction containing $\mathrm{VE}$ was recovered, and the solvent was then eliminated by evaporation under $\mathrm{N}_{2}$ flow. The residue was dissolved into $0.4 \mathrm{~mL}$ of a mixture of methanol, dichloromethane, and tetrahydrofuran (39/21/40, vol/ $\mathrm{vol} / \mathrm{vol})$. Quantification was carried out with the same HPLC as that described for plasma determination, equipped with a C18 5- $\mu \mathrm{m}$ column (Interchim) and a UV-visible detector (Kontron 430). The mobile phase was methanol at a flow rate of $1.5 \mathrm{~mL} / \mathrm{min}$.

\section{FA Determination}

Total lipids from forages were extracted with chloroform and methanol $(2: 1 \mathrm{vol} / \mathrm{vol})$ by the method of Folch et al. (1957). Then, FA from forages, barley, and soybean meal were extracted and methylated as described by Sukhija and Palmquist (1988). Tricosanoate (Sigma, Saint-Quentin Fallavier, France) was used as the internal standard. Fatty acids in lyophilized milk were directly methylated according to Loor et al. (2005), except that the $1 \mathrm{~mL}$ of $14 \%$ boron trifluoride in methanol was replaced by $75 \mu \mathrm{L}$ of $12 \mathrm{~N} \mathrm{HCl}$. Samples were injected by an autosampler into a Trace-GC 2000 Series gas chromatograph equipped with a flame-ionization detector (Thermo Finnigan, Les Ulis, France). Fatty acid methyl esters were separated on a $100 \times 0.25 \mathrm{~mm}$ i.d. fused silica capillary column (CP-Sil 88, Chrompack, Middelburg, Netherlands). A butter reference standard (CRM 164, Commission of the European Communities, Community Bureau of Reference, Brussels, Belgium) was used to determine individual recoveries and correction factor from $\mathrm{C} 4$ to $\mathrm{C} 10$.

\section{Calculations and Statistical Analysis}

A covariate term was calculated as the deviation between each individual cow and the mean of the cow's breed. This covariate term using the data obtained from the last week of the preexperimental period was included in the model. Data were analyzed as repeated measurements using the MIXED procedure of SAS (SAS Institute, 1996), with type of forage (hay vs. grass silage), feeding level (high vs. low), breed, time, and their interactions as fixed effects, and animal as random effect. For adipose tissues, data were analyzed 
Table 2. Intake, milk production and composition, and energy and protein balance in cows fed diets differing in forage and feeding level ${ }^{1}$

\begin{tabular}{|c|c|c|c|c|c|c|c|c|c|c|}
\hline & \multicolumn{2}{|c|}{ Hay } & \multicolumn{2}{|c|}{ Grass silage } & \multirow[b]{2}{*}{ SE } & \multicolumn{5}{|c|}{ Effects $^{2}$} \\
\hline & High & Low & High & Low & & $\mathrm{F}$ & $\mathrm{L}$ & $\mathrm{F} \times \mathrm{L}$ & $\mathrm{B}$ & $\mathrm{L} \times \mathrm{B}$ \\
\hline \multicolumn{11}{|l|}{ Intake } \\
\hline Net energy, Mcal/d & 29.1 & 23.8 & 26.1 & 19.0 & 0.5 & $* * *$ & $* * *$ & $*$ & $* * *$ & $*$ \\
\hline Protein, $\mathrm{g}$ of $\mathrm{PDI}^{3} / \mathrm{d}$ & 1,878 & 1,820 & 1,543 & 1,451 & 47 & $* * *$ & NS & NS & $* * *$ & NS \\
\hline Milk yield, kg/d & 21.7 & 20.7 & 20.3 & 18.3 & 0.5 & $* * *$ & $* * *$ & NS & $* * *$ & NS \\
\hline Milk yield $4 \%, \mathrm{~kg} / \mathrm{d}$ & 21.7 & 20.0 & 20.9 & 17.7 & 0.4 & $* * *$ & $* * *$ & NS & $* * *$ & NS \\
\hline \multicolumn{11}{|l|}{ Milk fat } \\
\hline $\mathrm{g} / \mathrm{kg}$ & 39.6 & 38.0 & 42.4 & 38.4 & 0.7 & $*$ & $* * *$ & NS & NS & NS \\
\hline $\mathrm{g} / \mathrm{d}$ & 873 & 779 & 855 & 684 & 22 & $*$ & $* * *$ & $\dagger$ & $* * *$ & $\dagger$ \\
\hline \multicolumn{11}{|l|}{ Milk protein } \\
\hline $\mathrm{g} / \mathrm{kg}^{\mathrm{T}}$ & 34.7 & 32.8 & 32.4 & 31.4 & 0.3 & $* * *$ & $* * *$ & NS & $* * *$ & $*$ \\
\hline $\mathrm{g} / \mathrm{d}$ & 750 & 673 & 655 & 565 & 16 & $* * *$ & $* * *$ & NS & $* * *$ & $*$ \\
\hline \multicolumn{11}{|l|}{ Balance } \\
\hline Net energy, Mcal/d & 3.40 & -0.63 & 1.27 & -2.82 & 0.42 & $* * *$ & $* * *$ & NS & $*$ & NS \\
\hline Protein, g of $\mathrm{PDI}^{3} / \mathrm{d}$ & 337 & 464 & 60 & 258 & 37 & $* * *$ & $* * *$ & NS & NS & NS \\
\hline
\end{tabular}

${ }^{1}$ Values are means for 8 cows per group over $8 \mathrm{wk}$.

${ }^{2}$ Effects: $\mathrm{F}$ = forage, $\mathrm{L}=$ level, $\mathrm{B}=$ breed.

${ }^{3} \mathrm{PDI}=$ Proteins digestible in the intestine.

$\dagger P \leq 0.10 ; * P \leq 0.05 ; * * * P \leq 0.001$.

using the MIXED procedure of SAS (1996), with site (intermuscular, kidney, internal, subcutaneous), treatment (control, hay high, hay low), and their interactions as fixed effects and animal as random effect. Although cows from hay high and hay low groups were not slaughtered on the same day (d 36 and d 47, respectively), differences between these 2 groups were assumed to be related to feeding level. The effects of type of forage (control vs. hay) and feeding level (hay high vs. hay low) were assessed by contrast analysis.

\section{RESULTS}

Only effects related to type of forage, feeding level, and breed are reported in the tables. Effects related to time are presented in the figures.

\section{Intake, Milk Yield and Composition, Energy and Protein Balances, BW, and BCS}

In comparison to hay diets, grass silage diets led to lower intake of $\mathrm{NE}_{\mathrm{L}}$ and digestible protein, milk yield, milk fat secretion, milk protein content and secretion, $\mathrm{NE}_{\mathrm{L}}$ and protein balances, and higher milk fat content (Table 2). Protein intake was similar, but $\mathrm{NE}_{\mathrm{L}}$ intake, milk yield, milk fat and protein contents and secretions, and $\mathrm{NE}_{\mathrm{L}}$ balance were higher, and protein balance was lower for cows fed high levels compared with low feeding levels.

The decrease in $\mathrm{NE}_{\mathrm{L}}$ intake and in milk fat secretion was less marked for hay than for grass silage diets $(-5.3$ vs. $-7.1 \mathrm{Mcal} / \mathrm{d},-94 \mathrm{vs} .-171 \mathrm{~g} / \mathrm{d}$, respectively). The decrease in milk yield, milk fat and protein content, milk protein secretion, and $\mathrm{NE}_{\mathrm{L}}$ balance $(-4.1 \mathrm{Mcal} /$ d), and the increase in protein balance were similar between both hay and grass silage diets. The negative $\mathrm{NE}_{\mathrm{L}}$ balance at low feeding level was more marked in the grass silage group ( $-2.82 \mathrm{Mcal} / \mathrm{d})$ than in the hay group ( $-0.63 \mathrm{Mcal} / \mathrm{d})$. Protein balance was positive for both groups. Differences in intake and milk yield between breeds induced lower $\mathrm{NE}_{\mathrm{L}}$ balances for Holstein than for Montbeliarde cows.

Between the beginning and the end of the experiment, BW was shown to slightly decrease $(-14 \mathrm{~kg})$ with grass silages diets and slightly increase $(+6 \mathrm{~kg})$ with hay diets $(P<0.005$, data not shown). These variations were not affected by feeding level. Body condition score was shown to slightly increase $(+0.3)$, irrespective of type of forage and feeding level, but this increase was lower than the accuracy of measurement $(>0.5)$.

\section{Plasma Metabolites}

Glycemia remained similar between treatments (Table 3). At the high feeding level, plasma concentrations of NEFA, BHBA, and urea remained similar for both hay and grass silage diets. The decrease in feeding level induced an increase in plasma concentrations of NEFA in the grass silage group only, and an increase in uremia that was more marked for hay than for grass silage diets. Plasma concentrations of BHBA were lower with the hay diets, whereas they were higher with the grass silage diet for cows fed high levels compared with low feeding levels. Uremia was lower in Holstein than in Montbeliarde cows ( 0.14 vs. $0.20 \mathrm{~g} / \mathrm{L})$. 
Table 3. Plasma concentration of metabolites in cows fed diets differing in forage and feeding level ${ }^{1}$

\begin{tabular}{|c|c|c|c|c|c|c|c|c|c|c|}
\hline & \multicolumn{2}{|c|}{ Hay } & \multicolumn{2}{|c|}{ Grass silage } & \multirow[b]{2}{*}{ SE } & \multicolumn{5}{|c|}{ Effects $^{2}$} \\
\hline & High & Low & High & Low & & $\mathrm{F}$ & $\mathrm{L}$ & $\mathrm{F} \times \mathrm{L}$ & B & $\mathrm{L} \times \mathrm{B}$ \\
\hline NEFA, $\mathrm{m} M$ & 0.057 & 0.042 & 0.049 & 0.180 & 0.040 & NS & NS & $\dagger$ & NS & NS \\
\hline BHBA, mM & 0.534 & 0.654 & 0.614 & 0.371 & 0.033 & $* *$ & $\dagger$ & $* * *$ & NS & NS \\
\hline Glucose, g/L & 0.588 & 0.590 & 0.610 & 0.583 & 0.024 & NS & NS & NS & NS & NS \\
\hline Urea, g/L & 0.156 & 0.278 & 0.114 & 0.165 & 0.024 & $* *$ & $* *$ & NS & $*$ & NS \\
\hline
\end{tabular}

${ }^{1}$ Values are means for 8 cows per group at d 50.

${ }^{2}$ Effects: $\mathrm{F}=$ forage, $\mathrm{L}=$ level, $\mathrm{B}=$ breed.

$\dagger P \leq 0.10 ; * P \leq 0.05 ; * * P \leq 0.01 ; * * * P \leq 0.001$.

\section{Carotenoids and VA in Plasma and Milk}

Plasma carotenoids consisted of lutein, 13-cis-, and all-trans-BC (Table 4). For both forages and feeding levels, lutein accounted for less than $3 \%$ of total carotenoids, on average, and the 13-cis isomer accounted for $22 \%$ of total BC. Lutein was slightly lower with grass silage than with hay diets $(0.053 \mathrm{vs} .0 .067 \mu \mathrm{g} / \mathrm{mL}$, respectively). Both 13-cis- and all-trans-BC plasma concentrations were higher with grass silage than with hay diets ( 0.99 vs. 0.53 and $3.71 \mathrm{vs.} 1.71 \mu \mathrm{g} / \mathrm{mL}$, respectively). In animals fed grass silage diets, plasma concentrations of $\mathrm{BC}$ increased slightly between $\mathrm{d} 1$ and 50 from 4.2 to $5.1 \mu \mathrm{g} / \mathrm{mL}$ (Figure 1). In animals fed hay diets, plasma concentrations of $\mathrm{BC}$ decreased from 3.8 to $1.7 \mu \mathrm{g} / \mathrm{mL}$ between $\mathrm{d} 1$ and 10 , then stabilized be- tween d 10 and d 50. The difference between hay and grass silage diets was significant after d 5. Lutein, 13cis-, all-trans-, and total BC concentrations were, on average, not affected by feeding level. Higher concentrations of plasma carotenoids in Holstein than in Montbeliarde were found with hay diets for lutein (0.079 vs. $0.054 \mu \mathrm{g} / \mathrm{mL})$, and with low feeding levels for BC (3.97 vs. $3.25 \mu \mathrm{g} / \mathrm{mL}$ ).

Carotenoids in milk consisted of all-trans-BC (Table 4). Traces of lutein were detected but could not be quantified. Concentrations of BC in milk [0.133 vs. $0.062 \mu \mathrm{g} /$ $\mathrm{mL}(3.64 \mathrm{vs} .1 .77 \mu \mathrm{g} / \mathrm{g}$ of fat)], as well as the amount secreted in milk ( $2.45 \mathrm{vs} .1 .31 \mathrm{mg} / \mathrm{d}$ ), were higher with grass silage than with hay diets, respectively. In animals fed grass silage diets, there was an increase in

Table 4. Plasma and milk concentrations of carotenoids, vitamins A and E, traceability indexes, and milk secretion of carotenoids, vitamins $\mathrm{A}$ and $\mathrm{E}$ in cows fed diets differing in forage and feeding level ${ }^{1}$

\begin{tabular}{|c|c|c|c|c|c|c|c|c|c|c|}
\hline & \multicolumn{2}{|c|}{ Hay } & \multicolumn{2}{|c|}{ Grass silage } & $\mathrm{SE}$ & \multicolumn{5}{|c|}{ Effects $^{2}$} \\
\hline \multicolumn{11}{|l|}{ Plasma } \\
\hline 13-Cis $\beta$-carotene, $\mu \mathrm{g} / \mathrm{mL}$ & 0.49 & 0.57 & 1.01 & 0.97 & 0.05 & $* * *$ & NS & NS & NS & $\dagger$ \\
\hline Trans- $\beta$-carotene, $\mu \mathrm{g} / \mathrm{mL}$ & 1.55 & 1.87 & 3.72 & 3.69 & 0.18 & $* * *$ & NS & NS & NS & * \\
\hline Total $\beta$-carotene, $\mu \mathrm{g} / \mathrm{mL}$ & 2.06 & 2.54 & 4.75 & 4.68 & 0.24 & $* * *$ & NS & NS & NS & $\dagger$ \\
\hline \multicolumn{11}{|l|}{ Milk } \\
\hline Trans- $\beta$-carotene, $\mu \mathrm{g} / \mathrm{mL}$ & 0.056 & 0.068 & 0.123 & 0.142 & 0.008 & $* * *$ & $\dagger$ & NS & NS & $* *$ \\
\hline Trans- $\beta$-carotene, $\mu \mathrm{g} / \mathrm{g}$ of $\mathrm{fat}^{4}$ & 1.64 & 1.90 & 3.21 & 4.06 & 0.20 & $* * *$ & $* *$ & NS & NS & $*$ \\
\hline Trans- $\beta$-carotene secreted, $\mathrm{mg} / \mathrm{d}$ & 1.20 & 1.42 & 2.44 & 2.45 & 0.14 & $* * *$ & NS & NS & $* *$ & $*$ \\
\hline Color index & 428 & 433 & 540 & 541 & 9 & $* * *$ & NS & NS & $* * *$ & NS \\
\hline Vitamin $\mathrm{E}, \mu \mathrm{g} / \mathrm{mL}$ & 0.555 & 0.650 & 0.887 & 1.005 & 0.045 & $* * *$ & * & NS & $\dagger$ & NS \\
\hline
\end{tabular}

${ }^{1}$ Values are means for 8 cows per group over 8 wk (carotenoids, vitamin E, traceability indexes) or at d 50 (vitamin A).

${ }^{2}$ Effects: $\mathrm{F}=$ forage, $\mathrm{L}=$ level, $\mathrm{B}=$ breed.

${ }^{3} \mathrm{~F} \times \mathrm{B}: P \leq 0.01$.

${ }^{4} \mathrm{~F} \times \mathrm{L} \times \mathrm{B}: P \leq 0.10$.

$\dagger P \leq 0.10 ; * P \leq 0.05 ; * * P \leq 0.01 ; * * * P \leq 0.001$. 

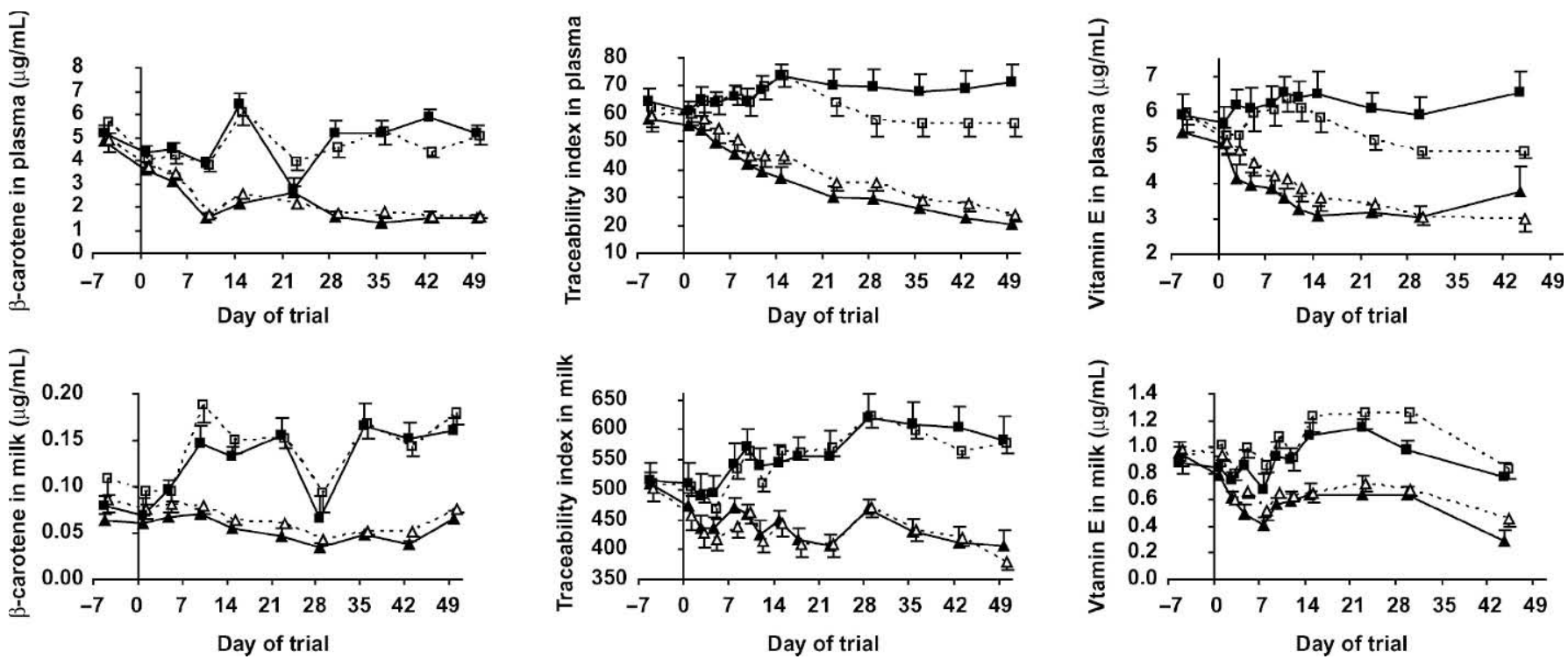

Figure 1. Evolution in $\beta$-carotene and vitamin $\mathrm{E}$ concentrations, and color index, in plasma and milk, in cows fed diets differing in forage and feeding level ( $\boldsymbol{\square}$ = grass silage high, $\square$ = grass silage low, $\boldsymbol{\Delta}$ = hay high, $\triangle$ = hay low). Means \pm SEM for 8 cows per group are presented.

carotenoid concentration in milk between $\mathrm{d} 1$ and 50 from 0.081 to $0.168 \mu \mathrm{g} / \mathrm{mL}$ ( 2.17 to $4.53 \mu \mathrm{g} / \mathrm{g}$ of fat), as well as in the amount secreted in milk from 1.68 to 2.95 $\mathrm{mg} / \mathrm{d}$ (Figure 1). In animals fed hay diets, concentrations in milk and the amount secreted in milk varied only slightly over time, and were similar between $\mathrm{d} 1$ and 50. Differences in BC concentrations in milk between hay and grass silage diets were significant after d 10. Beta-carotene concentrations in milk were lower for cows fed high levels compared with low feeding levels. This occurred mainly in Holstein cows. The amount of $\mathrm{BC}$ secreted in milk was not affected on average by feeding level. Beta-carotene secreted in milk was higher in Holstein than in Montbeliarde cows; this breed effect occurred mainly at low feeding level.

Concentrations of VA in plasma were similar between treatments, averaging $0.55 \mu \mathrm{g} / \mathrm{mL}$, and were higher in Holstein than in Montbeliarde (0.661 vs. $0.438 \mu \mathrm{g} / \mathrm{mL}$ ) cows. The concentrations of VA in milk were higher with grass silage than with hay diets [0.193 vs. 0.146 $\mu \mathrm{g} / \mathrm{mL}$ ( $4.78 \mathrm{vs} .3 .57 \mu \mathrm{g} / \mathrm{g}$ of fat)]. The same trend was observed for the amount of VA secreted in milk (3.93 vs. $3.20 \mathrm{mg} / \mathrm{d}$, respectively). Vitamin A concentrations in milk were lower for cows fed high levels compared with low feeding levels [152 vs. $191 \mu \mathrm{g} / \mathrm{mL}$ (3.59 vs. $4.89 \mu \mathrm{g} / \mathrm{g}$ of fat)]. This was mainly observed in Holstein cows. The amount of VA secreted in milk also tended to increase between high and low feeding levels (3.17 vs. $3.83 \mathrm{mg} / \mathrm{d}$ ), and was higher in Holstein than in Montbeliarde cows.

\section{Carotenoids in Adipose Tissues}

The amount of intermuscular, kidney, internal (pelvic and channel), subcutaneous (Table 5), and total adipose tissue did not vary significantly among treatments. Total adipose tissues averaged $68.1 \pm 19.5,54.8 \pm 16.9$, and $58.5 \pm 15.2 \mathrm{~kg}$ for control, hay high, and hay low treatments, respectively (data not shown). Carotenoids detected in adipose tissues consisted of lutein, alltrans-, and 13-cis-BC (Table 5). Lutein accounted for 6 to $14 \%$ of total carotenoids. The 13-cis isomer accounted for 17 to $31 \%$ of total BC. Concentrations of lutein were similar among tissues, whereas concentrations of alltrans- and 13-cis-BC were higher in the kidney than in the other adipose tissues. Pools of all-trans- and 13-cis$\mathrm{BC}$ in adipose tissues decreased by 35 and $48 \%$ between grass silage and hay diets, respectively. The same trend was observed for lutein $(-27 \%)$ but failed to reach statistical significance $(P=0.195)$. Pools of carotenoids in adipose tissues were similar for both hay high and hay low diets.

\section{Vitamin E in Plasma and Milk}

Plasma VE concentrations were higher with grass silage than with hay diets ( 5.90 vs. $3.94 \mu \mathrm{g} / \mathrm{mL}$, respectively; Table 4). In animals fed grass silage diets, plasma VE concentrations increased from 5.74 to 6.61 $\mu \mathrm{g} / \mathrm{mL}$ between $\mathrm{d} 1$ and 45 in the high group, and did not significantly decrease in the low group (Figure 1). In animals fed hay diets, there was a decrease from 5.2 
Table 5. Concentrations and pools of carotenoids in adipose tissues of Montbeliarde cows fed diets differing in forage and feeding level ${ }^{1}$

\begin{tabular}{|c|c|c|c|c|c|c|c|c|c|}
\hline & \multirow[b]{2}{*}{ Treatment $^{3}$} & \multicolumn{4}{|c|}{ Site } & \multirow[b]{2}{*}{ SE } & \multicolumn{3}{|c|}{ Effects $^{2}$} \\
\hline & & $\begin{array}{l}\text { Inter- } \\
\text { muscular }\end{array}$ & Kidney & Internal & $\begin{array}{l}\text { Sub- } \\
\text { cutaneous }\end{array}$ & & $\mathrm{S}$ & $\mathrm{T}$ & $\mathrm{S} \times \mathrm{T}$ \\
\hline \multicolumn{10}{|l|}{ Adipose tissue, $\mathrm{kg}$} \\
\hline & Control & 34.7 & 3.96 & 6.66 & 9.93 & & & & \\
\hline & Hay high & 30.1 & 2.73 & 5.42 & 8.13 & & & & \\
\hline & Hay low & 31.5 & 2.79 & 5.82 & 8.70 & 2.06 & $* * *$ & NS & NS \\
\hline \multicolumn{10}{|c|}{ Concentrations, $\mu \mathrm{g} / \mathrm{g}$} \\
\hline \multirow[t]{3}{*}{ Lutein } & Control & 0.22 & 0.23 & 0.26 & 0.25 & & & & \\
\hline & Hay high & 0.20 & 0.22 & 0.20 & 0.21 & & & & \\
\hline & Hay low & 0.20 & 0.21 & 0.18 & 0.20 & 0.03 & NS & NS & NS \\
\hline \multirow[t]{3}{*}{ Trans- $\beta$-carotene } & Control & 1.57 & 2.65 & 1.45 & 1.57 & & & & \\
\hline & Hay high & 1.26 & 3.11 & 1.84 & 1.59 & & & & \\
\hline & Hay low & 0.99 & 2.12 & 1.22 & 1.33 & 0.41 & $* * *$ & $\mathrm{NS}$ & NS \\
\hline \multirow[t]{3}{*}{ 13-Cis- $\beta$-carotene } & Control & 0.57 & 0.87 & 0.62 & 0.62 & & & & \\
\hline & Hay high & 0.40 & 0.64 & 0.37 & 0.46 & & & & \\
\hline & Hay low & 0.27 & 0.52 & 0.33 & 0.60 & 0.11 & $* *$ & NS & NS \\
\hline \multirow[t]{3}{*}{ Total $\beta$-carotene } & Control & 2.14 & 3.52 & 2.07 & 2.18 & & & & \\
\hline & Hay high & 1.65 & 3.75 & 2.21 & 2.05 & & & & \\
\hline & Hay low & 1.26 & 2.64 & 1.54 & 1.92 & 0.47 & $* * *$ & NS & NS \\
\hline \multicolumn{10}{|l|}{ Pools, mg } \\
\hline \multirow[t]{3}{*}{ Lutein } & Control & 7.56 & 1.00 & 1.65 & 2.54 & & & & \\
\hline & Hay high & 5.87 & 0.56 & 1.05 & 1.76 & & & & \\
\hline & Hay low & 6.12 & 0.55 & 1.02 & 1.70 & 0.47 & $* * *$ & NS & NS \\
\hline \multirow[t]{3}{*}{ Trans- $\beta$-carotene } & Control & 53.3 & 12.6 & 9.52 & 15.5 & & & & \\
\hline & Hay high & 37.4 & 6.6 & 9.3 & 12.0 & & & & \\
\hline & Hay low & 29.9 & 4.86 & 6.74 & 10.5 & 3.2 & * & $* * *$ & $*$ \\
\hline \multirow[t]{3}{*}{ 13-Cis- $\beta$-carotene } & Control & 19.4 & 3.8 & 4.1 & 6.5 & & & & \\
\hline & Hay high & 11.8 & 1.7 & 1.9 & 3.5 & & & & \\
\hline & Hay low & 8.3 & 1.3 & 1.8 & 4.7 & 1.8 & * & $* * *$ & $\dagger$ \\
\hline \multirow[t]{3}{*}{ Total $\beta$-carotene } & Control & 72.7 & 16.5 & 13.6 & 22.0 & & & & \\
\hline & Hay high & 49.2 & 8.4 & 11.2 & 15.5 & & & & \\
\hline & Hay low & 38.2 & 6.1 & 8.5 & 15.2 & 4.5 & $* *$ & $* * *$ & $*$ \\
\hline
\end{tabular}

${ }^{1}$ Values are means for 4 cows per group at $\mathrm{d}-4$ (control), d 36 (hay high), and d 46 (hay low).

${ }^{2}$ Effects: $\mathrm{S}=$ site; $\mathrm{T}=$ treatment.

${ }^{3}$ Control = grass silage-based diet fed ad libitum; Hay high = hay-based diet fed to $\mathrm{NE}_{\mathrm{L}}$ and nitrogen requirements according to the INRA (1989); Hay low = hay-based diet energetically underfed by reducing the amount of concentrate $(-6.2 \mathrm{Mcal} \mathrm{NE} / \mathrm{d})$.

$\dagger P \leq 0.10 ; * P \leq 0.05 ; * * P \leq 0.01 ; * * * P \leq 0.001$.

to $3.7 \mu \mathrm{g} / \mathrm{mL}$ between $\mathrm{d} 1$ and 12 , followed by stabilization between $\mathrm{d} 12$ and 45. Differences between hay and grass silage diets were significant after $d 3$. With the hay diets, plasma VE concentrations were not affected by feeding level, whereas with the grass silage diets, they were higher for cows fed high levels compared with low feeding levels. The difference occurred after d 10 and was significant after $d 15$. There were higher concentrations of VE in Holstein than in Montbeliarde cows at the high feeding level (5.52 vs. $4.50 \mu \mathrm{g} / \mathrm{mL})$.

The concentration of VE in milk, as well as the amount secreted in milk, was higher with grass silage than with hay diets $[0.946$ vs. $0.603 \mu \mathrm{g} / \mathrm{mL}$ (23.8 vs. $15.8 \mu \mathrm{g} / \mathrm{g}$ of fat), and 18.5 vs. $13.3 \mathrm{mg} / \mathrm{d}$, respectively]. In animals fed grass silage diets, VE concentration in milk and the amount secreted in milk increased slightly between $\mathrm{d} 1$ and 15 ( +23 and $+13 \%$, respectively), then decreased to a point at which milk concentrations were similar and the amount secreted in milk was $26 \%$ lower at $\mathrm{d} 45$ than at $\mathrm{d} 1$. In animals fed hay diets, between $\mathrm{d} 1$ and 8 the VE concentration in milk decreased from 0.873 to $0.455 \mu \mathrm{g} / \mathrm{mL}$ (22.71 to $12.20 \mu \mathrm{g} / \mathrm{g}$ of fat), and the amount secreted in milk decreased from 20.0 to 9.8 $\mathrm{mg} / \mathrm{d}$; both then stabilized between $\mathrm{d} 8$ and 45 . Differences in VE concentrations in milk between hay and grass silage diets were significant after d 5 . Vitamin $\mathrm{E}$ concentrations in milk were lower, whereas the amount secreted in milk was similar for cows fed high levels compared with low feeding levels. The concentration of VE in milk tended to be lower in Holstein than in Montbeliarde cows [0.73 vs. $0.82 \mu \mathrm{g} / \mathrm{mL}$ (18.7 vs. 20.9 $\mu \mathrm{g} / \mathrm{g}$ of fat)].

\section{Cl of Plasma and Milk}

The CI of plasma was higher with grass silage than with hay diets (66.0 vs. 40.8 , respectively; Table 4$)$. In 

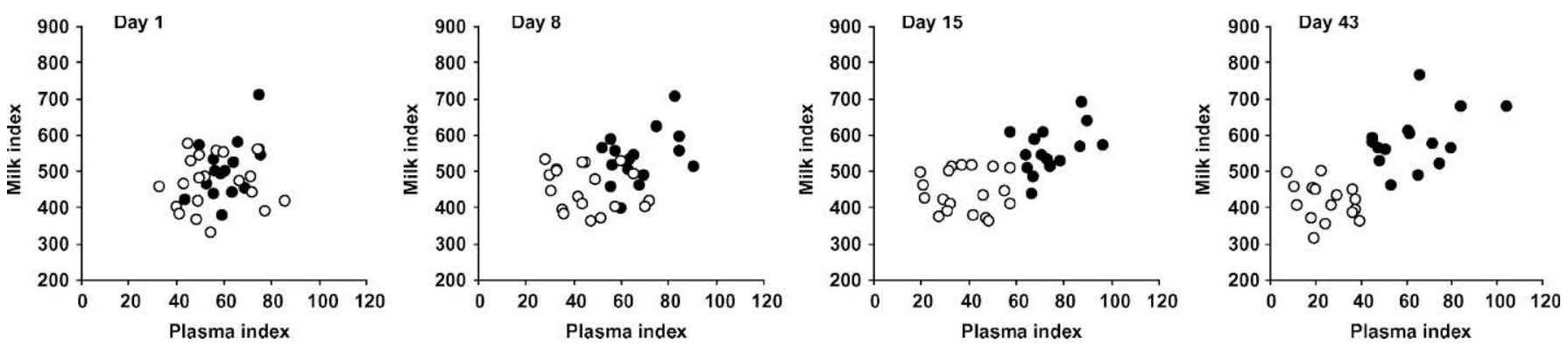

Figure 2. Link between plasma and milk color index in cows fed hay $(\bigcirc)$ or grass silage $(\bullet)$ diets after 1 , 8, 15, and $43 \mathrm{~d}$ of treatment.

animals fed grass silage diets, it did not significantly vary according to time (Figure 1), whereas in animals fed hay diets, it decreased rapidly between $\mathrm{d} 1$ and 5 and slowly between $\mathrm{d} 5$ and 43 , and then stabilized between $\mathrm{d} 43$ and 50 . Differences between hay and grass silage diets were significant after $d 3$. With the hay diets, the CI of plasma was not affected by feeding level, whereas with the grass silage diets, it was higher for cows fed high levels compared with low feeding levels. The difference occurred after $\mathrm{d} 15$ and reached significance after d 29. The CI of plasma was higher in Holstein than in Montbeliarde cows (58.4 vs. 48.4, respectively).

The evolution of the CI of milk was similar to the evolution of the $b$ parameter provided by the $L, a, b$ determination. This CI was higher with grass silage than with hay diets (541 vs. 431 , respectively). In animals fed grass silage diets, it increased from 500 to 615 between $\mathrm{d} 1$ and 36, then slightly decreased to 575 at d 50 (Figure 1). In animals fed hay diets, the milk CI decreased rapidly between $\mathrm{d} 1$ and 3 , slowly between $\mathrm{d} 3$ and 24, then stabilized between d 24 and 50. Differences in the CI of milk between hay and grass silage diets were significant after $d 1$. The CI of milk was not affected between high and low feeding levels, but was lower in Holstein than in Montbeliarde cows (466 vs. 500 , respectively).

From a traceability standpoint, plasma CI permitted an accurate distinction (overlapping for 1 of the 16 measurements) between different forage regimens from $d$ 15 and thereafter (Figure 2). The milk indexes alone were unable to provide a complete discrimination, even after $\mathrm{d} 50$, but the simultaneous use of plasma and milk indexes proved effective in discriminating $100 \%$ of the cows according to diet from d 15 and thereafter.

\section{Fatty Acid Composition in Diets and Milk}

Intake of $c i s-9, c i s-12$ C18:2 was lower whereas intake of $c i s-9$,cis-12,cis-15 C18:3 was higher with grass silage than with hay diets (122 vs. 198 and 153 vs. $112 \mathrm{~g} / \mathrm{d}$, respectively, Table 6 ).

Type of forage and feeding level had no effect on milk fatty acid percentages, except for C10 to C14 FA, and linoleic and linolenic acids $(P<0.001)$. The $\mathrm{C} 10$ to $\mathrm{C} 14$ FA and cis-9,cis-12 C18:2 percentages were lower whereas linolenic acid percentages were higher with grass silage than with hay diets $(-1.9,-0.5$, and +0.1 $\mathrm{g} / 100 \mathrm{~g}$, respectively). Linoleic acid percentage was higher whereas rumenic acid (cis-9,trans-11 C18:2) percentage was lower for cows fed high levels compared with low feeding levels. The difference in rumenic acid percentage between feeding levels was more marked with grass silage than with hay diets $(+0.22$ vs. +0.09 $\mathrm{g} / 100 \mathrm{~g}, P<0.01)$. Linolenic acid percentage tended to decrease at low feeding level $(-0.05 \mathrm{~g} / 100 \mathrm{~g})$ with hay diets whereas it increased with grass silage diets $(+0.04$ g/100 g, $P<0.01$ ). Breed effect was significant for all fatty acid percentages, except for short- and mediumchain FA and cis-9 C18:1. Holstein cows displayed higher percentages of C16:0 (+1.45/100 g), C18:0 $(+1.00$ $\mathrm{g} / 100 \mathrm{~g}$ ), and vaccenic acid (trans-11 C18:1; +0.05 g/100 $\mathrm{g})$, and lower percentages of rumenic $(-0.05 \mathrm{~g} / 100 \mathrm{~g})$, linoleic $(-0.12 \mathrm{~g} / 100 \mathrm{~g})$, and linolenic acids $(-0.06 \mathrm{~g} / 100$ g) than did Montbeliarde cows.

Yields of short- and medium-chain FA, C18:0, cis-9 C18:1, linoleic, and rumenic acids were lower with grass silage than with hay diets. Low feeding level decreased the yields of short-chain FA and C18 FA, but increased rumenic acid yield. Breed effect was significant for all fatty acid percentages and yields, except for C10 to C14 FA and rumenic acid. Holstein cows gave higher yields of milk FA than did Montbeliarde cows $(+13.4,+80.7$, $+20.8,+21.4,+1.3,+1.9$, and $0.4 \mathrm{~g} / \mathrm{d}$ for yields of $\mathrm{C} 4$ to C8, C16:0, C18:0, cis-9 C18:1, trans-11 C18:1, cis-9, cis$12 \mathrm{C} 18: 2$, and cis-9,cis-12, cis-15 C18:3, respectively).

\section{DISCUSSION}

Intakes of $\mathrm{NE}_{\mathrm{L}}$ and digestible protein were higher with hay than with grass silage diets. This resulted 
Table 6. Fatty acids intake and milk fatty acid composition and yield in cows fed diets differing in forage and feeding level ${ }^{1}$

\begin{tabular}{|c|c|c|c|c|c|c|c|c|c|c|}
\hline & \multicolumn{2}{|c|}{ Hay } & \multicolumn{2}{|c|}{ Grass silage } & \multirow[b]{2}{*}{$\mathrm{SE}$} & \multicolumn{5}{|c|}{ Effects $^{2}$} \\
\hline & High & Low & High & Low & & $\mathrm{F}$ & $\mathrm{L}$ & $\mathrm{F} \times \mathrm{L}$ & B & $\mathrm{L} \times \mathrm{B}$ \\
\hline \multicolumn{11}{|l|}{ Intake, $\mathrm{g} / \mathrm{d}$} \\
\hline $\mathrm{C} 12: 0$ & 1.3 & 1.2 & 1.3 & 1.2 & & & & & & \\
\hline C14:0 & 3.3 & 2.9 & 3.1 & 2.7 & & & & & & \\
\hline C16:0 & 101.8 & 85.3 & 92.4 & 72.4 & & & & & & \\
\hline C18:0 & 11.3 & 10.5 & 9.5 & 8.7 & & & & & & \\
\hline Cis-9 C18:1 & 66.8 & 52.0 & 41.8 & 27.0 & & & & & & \\
\hline Cis-9,cis-12 C18:2 & 221.0 & 175.7 & 144.0 & 99.8 & & & & & & \\
\hline Cis-9,cis-12,cis-15 C18:3 & 111.2 & 112.3 & 157.1 & 149.4 & & & & & & \\
\hline \multicolumn{11}{|l|}{ Milk percentage } \\
\hline $\mathrm{C} 4+\mathrm{C} 6+\mathrm{C} 8$ & 7.01 & 7.23 & 7.25 & 7.16 & 0.18 & NS & NS & NS & NS & NS \\
\hline $\mathrm{C} 10+\mathrm{C} 12+\mathrm{C} 14$ & 21.99 & 21.55 & 20.26 & 19.65 & 0.56 & $* *$ & NS & NS & NS & NS \\
\hline $\mathrm{C} 16: 0$ & 35.03 & 36.38 & 38.11 & 35.57 & 0.74 & NS & NS & * & $\dagger$ & NS \\
\hline $\mathrm{C} 18: 0^{2}$ & 6.30 & 7.01 & 6.68 & 6.84 & 0.33 & NS & NS & NS & $* * *$ & NS \\
\hline Cis-9 C18:1 & 13.61 & 13.47 & 13.08 & 12.25 & 0.71 & NS & NS & NS & NS & NS \\
\hline Trans-11 C18:1 & 0.51 & 0.45 & 0.53 & 0.48 & 0.04 & NS & NS & NS & $\dagger$ & NS \\
\hline Cis-9,trans-11 C18:2 & 0.29 & 0.38 & 0.22 & 0.44 & 0.03 & NS & $* * *$ & * & $\dagger$ & $\mathrm{NS}$ \\
\hline Cis-9,cis-12 C18:2 & 1.77 & 1.40 & 1.17 & 0.95 & 0.06 & $* * *$ & $* * *$ & NS & $\dagger$ & NS \\
\hline Cis-9,cis-12,cis-15 C18:3 & 0.41 & 0.36 & 0.47 & 0.51 & 0.02 & $* * *$ & NS & $\dagger$ & $\dagger$ & NS \\
\hline \multicolumn{11}{|l|}{ Milk yield, $\mathrm{g} / \mathrm{d}$} \\
\hline $\mathrm{C} 4+\mathrm{C} 6+\mathrm{C} 8$ & 60.3 & 57.0 & 59.7 & 45.8 & 2.5 & $*$ & $* *$ & * & $* * *$ & NS \\
\hline $\mathrm{C} 10+\mathrm{C} 12+\mathrm{C} 14$ & 192.1 & 171.3 & 166.3 & 123.7 & 7.0 & $* *$ & NS & NS & NS & NS \\
\hline C16:0 & 302.4 & 285.8 & 311.5 & 231.4 & 11.6 & $\dagger$ & $* * *$ & * & $* * *$ & NS \\
\hline $\mathrm{C} 18: 0^{3}$ & 59.1 & 56.7 & 50.1 & 46.0 & 2.8 & $* *$ & NS & NS & $* * *$ & NS \\
\hline Cis-9 C18:1 & 117.2 & 106.6 & 108.8 & 72.7 & 6.6 & $* *$ & $* *$ & $\dagger$ & $* *$ & NS \\
\hline Trans-11 C18:1 & 4.7 & 3.4 & 4.7 & 2.5 & 0.4 & NS & $* * *$ & NS & $* * *$ & NS \\
\hline Cis-9,trans-11 C18:2 & 2.3 & 3.0 & 1.8 & 2.7 & 0.2 & $\dagger$ & **** & NS & NS & NS \\
\hline Cis-9,cis-12 C18: $2^{4}$ & 15.5 & 10.5 & 9.5 & 6.3 & 0.7 & $* * *$ & $* * *$ & NS & * & NS \\
\hline Cis-9,cis-12,cis-15 C18:3 & 3.6 & 2.7 & 3.8 & 3.3 & 0.3 & NS & $*$ & NS & $\dagger$ & NS \\
\hline
\end{tabular}

${ }^{1}$ Values are means for 8 cows per group at d 50

${ }^{2}$ Effects: $\mathrm{F}=$ forage, $\mathrm{L}=$ level, $\mathrm{B}=$ breed.

${ }^{3} \mathrm{~F} \times \mathrm{L} \times \mathrm{B}, P \leq 0.05$.

${ }^{4} \mathrm{~F} \times \mathrm{B}, P \leq 0.10$.

$\dagger P \leq 0.10 ; * P \leq 0.05 ; * * P \leq 0.01 ; * * * P \leq 0.001$.

from an underestimation of the nutritive value of the hay. Consequently, the $\mathrm{NE}_{\mathrm{L}}$ balance was higher than expected for hay diets, and at the low feeding level, a negative $\mathrm{NE}_{\mathrm{L}}$ balance was effectively achieved only with the grass silage diet. This is consistent with the higher plasma NEFA concentration observed in the "low grass silage" group. Nevertheless, the decrease in $\mathrm{NE}_{\mathrm{L}}$ balance between high and low feeding levels was similar for both hay and grass silage diets $(-4.1 \mathrm{Mcal} /$ d), thereby justifying a multifactorial analysis of data.

\section{Diversity of Carotenoids in Plasma, Milk, and Adipose Tissues}

The total BC found in plasma was composed of 76 to $79 \%$ of all-trans- and 21 to $24 \%$ of 13 -cis isomer. The presence of 13-cis-BC in the plasma of cows has already been reported (B. Martin and P. Grolier, INRA, 63122 Theix, France, personal communication). Although it was found in plasma, 13-cis BC was not detected in milk, which is consistent with Martin et al. (2004). Lu- tein was found in plasma, accounting for 1 to $3 \%$ of total carotenoids, which is consistent with other results in both dairy cows (B. Martin and P. Grolier, INRA, 63122 Theix, France, personal communication) and steers (Yang et al., 1992). Only traces of lutein were determined in milk, whereas others (Havemose et al., 2004; Martin et al., 2004) were able to recover significant amounts. This may be related to plasma lutein concentrations, which were low in the present study $(0.05$ to $0.06 \mu \mathrm{g} / \mathrm{mL}$ ) compared with other previously reported results $(0.13$ to $0.23 \mu \mathrm{g} / \mathrm{mL}$; Martin et al., 2004).

The proportion of lutein in total carotenoids was higher in adipose tissue (6 to 14\%) than in plasma (1 to $3 \%$ ), which is consistent with results reported for steers (Yang et al., 1992). This may suggest that uptake of lutein from the blood by adipose tissue is more efficient than for BC, or that there is only limited release of lutein from adipose tissues into the blood. It is possible that $\mathrm{BC}$ is taken up by adipose tissue as efficiently as lutein and that it was partially cleaved in situ into 
VA. To date, there are no data to support these hypotheses. As suggested for VE, adipose tissue probably acquires carotenoids during low-density lipoprotein (LDL) uptake via the LDL receptor of high-density lipoprotein-mediated delivery systems. No nonspecific transfer of carotenoids between lipoproteins and adipose cell membranes has yet been demonstrated. To our knowledge, the presence of 13-cis-BC in bovine adipose tissues is reported for the first time in the present study, and its contribution to total $\mathrm{BC}$ was comparable in both adipose tissues (17 to $31 \%$ ) and plasma (21 to $24 \%$ ). Concentrations of total $\mathrm{BC}$ were higher in kidney fat than in the other adipose tissues, which is in contrast with other reports of a higher or similar concentration in subcutaneous compared with kidney fat in beef cattle (Knight et al., 1996; Mora et al., 2001; Reynoso et al., 2004). Differences in BC concentrations between adipose tissues could be related to differences in adipose cellularity, as suggested by Strachan et al. (1993). In dairy cows, adipocyte volume is much higher in kidney than in subcutaneous fat, whereas differences in adiposity between fat tissues are much lower in beef cattle (reviewed by Vernon, 1986).

\section{Extraction of Carotenoids and Vitamins from Plasma to Milk}

Assuming a flow through the mammary gland of 350 $\mathrm{mL}$ of plasma $/ \mathrm{mL}$ of milk produced, the amount of $\mathrm{BC}$, VA, and VE secreted daily into milk accounted for 0.008 , 0.095 , and $0.048 \%$ of daily plasma flux, respectively. These low rates of extraction are consistent with Jensen et al. (1999) for BC $(0.007 \%)$ and VE $(0.064 \%)$. The uptake of plasma $\mathrm{BC}$ and $\mathrm{VE}$ by the mammary gland may depend on lipoprotein lipase activity, as reported for $\alpha$-tocopherol in the rat (Martinez et al., 2002). This may explain the low extraction rate because only a minor part of these molecules are associated with very low density lipoproteins or chylomicrons in ruminants, in which transport in the blood of cattle has been reported to mainly occur via high-density lipoproteins and LDL for BC (Yang et al., 1992) and tocopherol (Al Senaidy, 1996). It should be pointed out that, although plasma and milk BC and VE concentrations were positively correlated $(P<0.0001)$, plasma concentration accounted for only 20 and $19 \%$ of variation in milk concentration of $\mathrm{BC}$ (residual standard error $=0.05$ ) and $\mathrm{VE}$ (residual standard error $=0.29$ ), respectively. The rate of extraction for VA was lower than the $0.43 \%$ reported by Jensen et al. (1999). In contrast to plasma, where the alcohol form is predominant, the majority of VA in milk is present as esters, arising mainly from synthesis by the mammary gland from the VA alcohol derived from the liver (Tomlinson et al., 1974), but also from the uptake of the VA ester derived from dietary intake. The transfer from plasma to milk may depend on the respective contributions of these 2 pathways to the total plasma pool.

\section{Effect of Type of Forage}

As expected, the concentrations of $\mathrm{BC}$ and $\mathrm{VE}$ in plasma and milk were higher with the grass silage than with the hay diets. This was consistent with the expected concentration differences of these micronutrients between forages. A positive relationship between $\mathrm{BC}$ and $\mathrm{VE}$ intake and their concentrations in plasma and milk has been reported previously (Havemose et al., 2004; Martin et al., 2004). It should be noted that there was a similar decrease in plasma concentration and milk secretion between grass silage and hay diets, averaging $-49 \%$ for $\mathrm{BC}$ and $-30 \%$ for $\mathrm{VE}$. The extent of the decrease in plasma concentration $(\mu \mathrm{g} / \mathrm{mL})$ of $\mathrm{BC}$ $(\mathrm{dBC})$ and $\mathrm{VE}(\mathrm{dVE})$ varied among individuals, and was highest in animals with the highest initial plasma concentrations $\left(\mathrm{BC}_{0}\right.$ and $\left.\mathrm{VE}_{0}\right)$ :

$$
\begin{aligned}
& \mathrm{dBC}=1.043 \times \mathrm{BC}_{0}-1.765\left(\mathrm{n}=16, \mathrm{R}^{2}=0.83\right) \\
& \mathrm{dVE}=0.536 \times \mathrm{VE}_{0}-0.457\left(\mathrm{n}=19, \mathrm{R}^{2}=0.76\right) .
\end{aligned}
$$

Similar results have been reported for plasma lutein in sheep shifted from grass to a stall diet (Prache et al., 2003). Consequently, the high variability in plasma concentration of $\mathrm{BC}$ and $\mathrm{VE}$ observed between individuals on grass silage diets $(\mathrm{SE}=1.5$ and $1.6 \mu \mathrm{g} / \mathrm{mL}$, respectively) was greatly attenuated on hay diets $(\mathrm{SE}=0.7$ and $0.9 \mu \mathrm{g} / \mathrm{mL}$, respectively). With hay diets, a minimal plasma concentration of $1.5 \mu \mathrm{g} / \mathrm{mL}$ of $\mathrm{BC}$ and $3.0 \mu \mathrm{g} /$ $\mathrm{mL}$ of $\mathrm{VE}$ was achieved, reflecting the balance between absorption, storage, catabolism, mobilization, and secretion.

The shift from grass silage to hay diet induced a significant decrease in the pools of all-trans- and 13cis-BC in adipose tissues, which is demonstrated for the first time in the present study. This same trend observed for lutein, which resulted primarily from a decrease in carotenoid concentration in adipose tissues, did not reach statistical significance, in line with Knight et al. (2001). Because plasma pools also decreased, it is not clear whether the decrease in $\mathrm{BC}$ pools in adipose tissues accounts for higher utilization or release by adipose tissues, or lower BC deposition in these tissues, as was suggested by Knight et al. (2001). Assuming a plasma volume of $27 \mathrm{~L}$ (i.e., $4.2 \%$ of $\mathrm{BW}$ ) and a homogeneous plasma concentration throughout the body, the $\mathrm{BC}$ plasma pool decreased from 130 to $62 \mathrm{mg}$ over the duration of the experiment. The $\mathrm{BC}$ pool in kidney and 
offals fat decreased from 125 to $84 \mathrm{mg}$, but these tissues represented only 81 to $85 \%$ of total adipose tissues. The decrease in BC pools was thus of similar magnitude in both plasma and adipose tissues, indicating that adipose tissues constitute a significant labile pool of $\mathrm{BC}$ in cows, at least during medium-term depletion. Unfortunately, short-term response was not assessed in the present study for adipose tissues.

The higher concentration of VA in milk in cows on the grass silage regimen than on the hay diets was not only due to the lower milk yield, because the amount of VA secreted in milk also tended to be higher. Nevertheless, compared with $\mathrm{BC}$, variations in VA in both plasma and milk were very low, possibly due to homeostatic regulation of both VA production from BC during absorption, and VA release by the liver. Lastly, the effect of type of forage on C10 to C14 FA, linoleic, and linolenic acid percentages in milk was in agreement with the few previous comparisons between hay and grass silage diets reported (Chilliard et al., 2001; Martin et al., 2004).

\section{Dynamic Aspects}

Variations in BC concentrations in plasma and milk with grass silage diets may be related to a temporary increase in DMI $(+1 \mathrm{~kg})$ during wk 2 and change in silo at the end of wk 3 . The decrease in plasma concentrations of $\mathrm{BC}$ and $\mathrm{VE}$ after the shift from grass silage to hay diet was very fast, reaching 0.21 and $0.12 \mu \mathrm{g} / \mathrm{mL}$ per $\mathrm{d}$ for $\mathrm{BC}$ and $\mathrm{VE}$, respectively, during the first 10 $\mathrm{d}$. This was consistent with the values $(0.13$ to $0.22 \mu \mathrm{g} /$ $\mathrm{mL}$ per d) obtained for BC in beef cattle shifted from high-carotene to low-carotene pellets and from pasture to feedlot (Knight et al., 1996). The minimal concentrations of BC and VE in plasma were achieved after 10 to $12 \mathrm{~d}$. This duration was shorter than the 30 to $50 \mathrm{~d}$ previously observed for $\mathrm{BC}$ in beef cattle (Knight et al., 1996). The lower initial plasma concentration here (3.8 $\mu \mathrm{g} / \mathrm{mL}$ ) than in Knight's study (5 to $11 \mu \mathrm{g} / \mathrm{mL}$ ) may not explain this shorter duration. Indeed, in the present study, the duration was similar among individuals and irrespective of their initial plasma concentration. The factors affecting either rate or duration of the plasma pool decrease of $\mathrm{BC}$ and $\mathrm{VE}$ during depletion remain unclear.

Variations in concentrations over time were quite different between milk and plasma for BC. The increase in concentration with grass silage diets was more marked in milk than in plasma, $(+107 \mathrm{vs} .+21 \%$, respectively), whereas the decrease in concentration with the hay diets was less marked ( -0 vs. $-55 \%$, respectively). This can only partly be explained by a concentration effect related to the decrease in milk yield, which ac- counted for only -10 and $-15 \%$ with grass silage and hay diets, respectively, between wk 1 and 8 . It may mainly be related to an increase in the extraction of $\mathrm{BC}$ from plasma to milk over time. In contrast, the evolution of milk concentrations of $\mathrm{VE}$ according to time was similar for both milk and plasma, suggesting that extraction of VE from plasma to milk was not modified. Because $\mathrm{BC}$ is a more highly hydrophobic molecule than $\mathrm{VE}$, it is possible that the efficiency of $\mathrm{BC}$ transfer from plasma to milk is highly dependent on the composition of milk-fat globules. It should be pointed out that differences in $\mathrm{BC}$ and $\mathrm{VE}$ concentrations in milk between grass silage and hay diets peaked 10 to $15 \mathrm{~d}$ after the switch from grass silage to hay diet, which is comparable to the observations in plasma in the present study.

\section{Effect of Feeding a Lower Energy Diet}

Effects of feeding level on plasma VE concentrations were observed only in animals fed grass silage. This is consistent with their $\mathrm{NE}_{\mathrm{L}}$ balance, as discussed above. The effects translated as a dramatic decrease in plasma concentrations of VE after d 10 in the "low grass silage" group. This is in agreement with Nockels et al. (1996) who reported that stress, including feed deprivation, was responsible for a decrease in VE concentrations in both plasma and liver in beef heifers. It is well known that different causes, such as critical physiological periods, breeding conditions, and feeding level (high lipid intake, micronutrient deficiency, or food deprivation) can activate peroxidation processes. In these critical physiological periods, 3 successive levels of cell antioxidant defense can be mobilized, including VE, in the prevention and restriction of the propagation step of peroxidation processes (Surai, 2002; Durand et al., 2005). It should be noted that net release of VE from labile pools was not sufficient to avoid the decrease in plasma concentrations, but that plasma concentrations remained higher than in depleted animals in this study. In contrast with plasma, VE concentrations in milk increased with underfeeding, which was due to a decrease in milk yield, whereas the amount of VE secreted in milk showed no change. Furthermore, the antioxidant status of milk remained unchanged (data not shown). It may be concluded that VE was taken up in priority by the mammary gland, and that uptake was increased in response to feed restriction. During lactation, the uptake of $\alpha$-tocopherol has been reported to be more efficient in the mammary gland than in adipose tissues in rats (Martinez et al., 2002). In dairy cows, the uptake of plasma VE by the mammary gland has been shown to increase with oxidative stress-inducing diets; i.e., diets enriched in polyunsaturated FA (Durand et al., 2005), although high amounts of antioxidant 
appeared not to efficiently prevent the oxidation of polyunsaturated FA in milk (Havemose et al., 2004).

No effect of feeding level was observed on plasma concentrations of carotenoids and VA. The small increase in $\mathrm{BC}$ concentration in milk between high and low feeding levels was mainly explained by the decrease in milk yield, whereas the amount of BC secreted in milk remained unaffected. In contrast, the increase in VA concentration in milk corresponded to a slight increase in VA secretion in the milk $(+0.7 \mathrm{mg} / \mathrm{d}$ in both diets). Under the hay diet regimen, no differences in $\mathrm{BC}$ concentrations and pools in adipose tissues were observed between high and low feeding levels. The ability of bovine adipose tissue to release BC during mobilization was thus not seen in the present study, where the $\mathrm{NE}_{\mathrm{L}}$ deficit was moderate. In cows near calving, Patterson (1965) reported a positive relationship between NEFA and carotenoid content of plasma, suggesting the ability of bovine adipose tissue to release BC. In the present study, with a $\mathrm{NE}_{\mathrm{L}}$ balance of -2.8 $\mathrm{Mcal} / \mathrm{d}$, nearly $400 \mathrm{~g} / \mathrm{d}$ fat was expected to be mobilized in the "low grass silage" group (Chilliard et al. 1987). Assuming that $\mathrm{BC}$ is released from fat tissues at the same rate as lipids, this may account for a release of almost $1 \mathrm{mg} / \mathrm{d}$ of BC, which is far from negligible when compared with the decrease measured on slaughtered animals $40 \mathrm{~d}$ after the shift from grass silage to hay diet. In the present study, this potential release did not influence BC plasma concentration or secretion in milk, but may partly explain the increased VA secretion into milk at the low feeding level.

Low feeding level had a slight effect on rumenic and linoleic acid percentages in milk. The increase of rumenic acid percentage and yield has been already reported by Jiang et al. (1996) in lactating cows fed a restricted diet. The decrease observed in yields of shortchain FA, C16:0, C18:0, and cis-9 C18:1 was mainly due to the decrease in fat yield at the low feeding level.

\section{Effect of Breed}

The experimental design used in the present work was not the best for assessing effect of breed, but certain interesting observations can nevertheless be highlighted. Breed appeared to be the main factor affecting plasma concentration and amount of VA secreted daily in milk, with both being higher in Holstein than in Montbeliarde cows. Although the following variables were primarily affected by type of forage, the plasma $\mathrm{CI}$ and concentrations of $\mathrm{BC}$ and $\mathrm{VE}$, as well as the amount of $\mathrm{BC}$ and $\mathrm{VE}$ secreted daily into milk, were higher in Holstein than in Montbeliarde cows, whereas milk CI was lower. Milk concentrations of BC, VA, and VE depended mainly on type of forage and feeding level, and were poorly affected by breed. Nevertheless, Holstein cows appeared to be more responsive than Montbeliarde cows to the effects of reducing feeding level on the increase in milk concentrations of $\mathrm{BC}$ and VA. Lastly, the effects of breed on C16:0 and rumenic acid percentages were in good agreement with previous data (Lawless et al., 1999). Furthermore, the higher FA yields observed with Holstein cows would appear to be due to their higher fat yield than that of Montbeliarde cows. However, the breed effect had only a minor impact on milk FA percentages and yield compared with feeding level factors.

\section{Use of $\mathrm{Cl}$ for Traceability}

Concentrations of BC explained 58 and $40 \%$ of the variability in $\mathrm{CI}$ in plasma and milk, respectively. The presence of other isomers or oxidized metabolites of carotenoids absorbing between 450 and $530 \mathrm{~nm}$ but not detected by our extraction method, may be questionable. Our results indicate that such a simple method of color determination is unable to accurately assess the concentration of BC in plasma and milk. However, from a traceability standpoint, although individual variability was high, the utilization of such CI in plasma and milk to trace feeding management of dairy cows remains an interesting perspective. In the present work, type of forage (hay vs. grass silage) fed to animals was highly discriminated by the CI measured in plasma and milk, which were able to accurately distinguish between the type of forage after $d 15$. This very simple and cheap method could be usefully applied in slaughterhouses to distinguish hay and grass silage diets. Its generalization to the discrimination of high-carotene diets (i.e., pasture or grass silage) or low-carotene diets (i.e., hay, corn silage, or concentrate-rich diets) is promising. In contrast, in this study, the discrimination of milk using milk CI alone remained inconclusive, even after $\mathrm{d} 50$. The overlap results from significant individual variability unrelated to milk fat content. This method proved more effective in previous studies also comparing hay and grass silage diets (Martin et al., 2005).

\section{CONCLUSIONS}

The present study showed that the switch from grass silage to hay diet induced a rapid decrease in BC and VE concentrations in plasma and milk, with maximal differences between diets being obtained after nearly 2 wk. We observed that concentrations of $\mathrm{BC}$ were highly variable between adipose tissues in dairy cows. This may be related to differences in adiposity between fat tissues. Adipose tissues appeared to constitute a labile 
pool of BC, at least during medium-term depletion, but we failed to observe a restitution of $\mathrm{BC}$ by adipose tissues with moderate underfeeding, where plasma concentrations and milk secretion of $\mathrm{BC}$ remained unaffected. Plasma concentrations of VE were depressed in underfed animals, possibly due to increased utilization. Vitamin E secretion into milk was not affected, suggesting that it was taken up in priority by the mammary gland. Beta-carotene concentrations were responsible for a substantial proportion of the variations in CI of plasma and milk. These CI appeared to be promising tools for traceability of high-carotene vs. low-carotene diets. Other studies providing dynamic and quantitative data on BC transfer from feed to milk and plasma, together with studies on the mechanisms controlling fluxes between plasma and adipose tissues, may help to determine the exact role of this micronutrient in the sensorial characteristics of milk and as potential tracer of animal feeding managements.

\section{ACKNOWLEDGMENTS}

We wish to thank the staff at Marcenat for animal care, zootechnical measurements, and sampling. We would also like to thank S. Klein Koerkamp for determination of the CI, R. Jailler for measurements at the slaughterhouse, P. Capitan, B. Lyan, M. Martineau, and M. Tourret for laboratory analyses, and J. B. Coulon, M. Petit, S. Prache, and B. Graulet for helpful discussions.

\section{REFERENCES}

Al Senaidy, A. M. 1996. Distribution of $\alpha$ - and $\gamma$-tocopherols within blood fractions of ruminants. Comp. Biochem. Physiol. A Physiol. 115:233-237.

AOAC. 1990. Official Methods of Analysis. Vol. I. 14th ed. Association of Official Analytical Chemists, Washington, DC.

Chilliard, Y., A. Ferlay, and M. Doreau. 2001. Effect of different types of forages, animal fat or marine oils in cow's diet on milk fat composition and secretion, especially conjugated linoleic acid (CLA) and polyunsaturated fatty acids. Livest. Prod. Sci. 70:31-48.

Chilliard, Y., B. Rémond, J. Agabriel, J. Robelin, and R. Vérité. 1987. Variations du contenu digestif et des réserves corporelles au cours du cycle gestation-lactation. Bull. Tech. CRZV Theix, INRA 70:117-131.

Durand, D., V. Scislowski, Y. Chilliard, D. Gruffat, and D. Bauchart. 2005. High fat rations and lipid peroxidation in ruminants; consequences on animal health and quality of products. Pages 137150 in Indicators of Milk and Beef Quality, EAAP Publ. no. 112. J. F. Hocquette and S. Gigli, ed. Wageningen Academic Publishers, The Netherlands.

Ferlay, A., and Y. Chilliard. 1999. Effects of the infusion of nonselective beta-, and selective beta1- or beta2-adrenergic agonists, on body fat mobilisation in underfed or overfed non-pregnant heifers. Reprod. Nutr. Dev. 39:409-421.

Folch, J., M. Lees, and G. H. Sloane Stanley. 1957. A simple method for the isolation and purification of total lipids from animal tissues. J. Biol. Chem. 226:497-509.
Havemose, M. S., M. R. Weisbjerg, W. L. P. Bredie, and J. H. Nielsen. 2004. Influence of feeding different types of roughage on the oxidative stability of milk. Int. Dairy J. 14:563-570.

INRA. 1989. Ruminant Nutrition. Recommended allowances and feed tables. R. Jarrige, ed. Institut National de la Recherche Agronomique, Paris, France.

Jensen, S. K., A. K. B. Johannsen, and J. E. Hermansen. 1999. Quantitative secretion and maximal secretion capacity of retinol, $\beta$-carotene and $\alpha$-tocopherol into cows'milk. J. Dairy Res. 66:511-522.

Jiang, J., L. Bjoerck, R. Fonden, and M. Emanuelson. 1996. Occurrence of conjugated cis-9, trans-11-octadecadienoic acid in bovine milk: Effect of feed and dietary regimen. J. Dairy Sci. 79:438-445.

Katsanidis, E., and P. B. Addis. 1999. Novel HPLC analysis of tocopherols, tocotrienols, and cholesterol in tissue. Free Radic. Biol. Med. 27:1137-1140.

Knight, T. W., A. F. Death, M. G. Lambert, and D. B. McDougall. 2001. The rate of reduction in carotenoid concentration in fat of steers fed a low carotenoid ration, and the role of increasing carcass fatness. Aust. J. Agric. Res. 53:1023-1032.

Knight, T. W., A. F. Death, P. D. Muir, M. Ridland, and T. K. Wyeth. 1996. Effects of dietary vitamin A on plasma and liver carotenoid concentrations and fat colour in Angus and Angus crossbred cattle. N.Z. J. Agric. Res. 39:281-292.

Lawless, F., C. Stanton, P. L'Escop, R. Devery, P. Dillon, and J. J. Murphy. 1999. Influence of breed on bovine milk cis-9, trans-11conjugated linoleic acid content. Livest. Prod. Sci. 62:43-49.

Loor, J. J., A. Ferlay, A. Ollier, M. Doreau, and Y. Chilliard. 2005. Relationship among trans conjugated fatty acids and bovine milk fat yield due to dietary concentrate and linseed oil. J. Dairy Sci. 88:726-740.

Lyan, B., V. Azais-Braesco, N. Cardinault, V. Tyssandier, P. Borel, M. C. Alexandre-Gouabau, and P. Grolier. 2001. Simple method for clinical determination of 13 carotenoids in human plasma using an isocratic high-performance liquid chromatographic method. J. Chromatogr. B Biomed. Sci. Appl. 751:297-303.

Martin, B., A. Cornu, N. Kondjoyan, A. Ferlay, I. Verdier-Metz, P. Pradel, E. Rock, Y. Chillard, J. B. Coulon, and J. L. Berdagué. 2005. Milk indicators for recognizing the types of forages eaten by dairy cows. Pages 127-136 in Indicators of Milk and Beef Quality, EAAP Publ. no. 112. J. F. Hocquette and S. Gigli, ed. Wageningen Academic Publishers, The Netherlands.

Martin, B., V. Fedele, A. Ferlay, P. Grolier, E. Rock, D. Gruffat, and Y. Chilliard. 2004. Effects of grass-based diets on the content of micronutrients and fatty acids in bovine and caprine dairy products. Grassland Sci. Eur. 9:876-886.

Martinez, S., C. Barbs, and E. Herrera. 2002. Uptake of alpha-tocopherol by the mammary gland but not by white adipose tissue is dependent on lipoprotein lipase activity around parturition and during lactation in the rat. Metabolism 51:1444-1451.

Mora, O., J. L. Romano, E. Gonzalez, F. J. Ruiz, R. Gomez, and A. Shimada. 2001. Presence of fed beta-carotene in digesta, excreta, blood, and hepatic and adipose tissue of Holstein steers. Can. J. Anim. Sci. 81:133-139.

Nockels, C. F., K. G. Odde, and A. M. Craig. 1996. Vitamin E supplementation and stress affect tissue $\alpha$-tocopherol content of beef heifers. J. Anim. Sci. 74:672-677.

Patterson, D. S. P. 1965. Plasma carotenoids and fat mobilization in stall-fed cattle. Nature 206:1069.

Prache, S., A. Priolo, and P. Grolier. 2003. Persistence of carotenoid pigments in the blood of concentrate-finished grazing sheep: Its significance for the traceability of grass-feeding. J. Anim. Sci. 81:360-367.

Prache, S., A. Priolo, R. Jailler, H. Dubroeucq, D. Micol, and B. Martin. 2002. Traceability of grass-feeding by quantifying the signature of carotenoid pigments in herbivores meat, milk and cheese. Grassland Sci. Eur. 7:592-593.

Reynoso, C. R., O. Mora, V. Nieves, A. Shimada, and E. Gonzalez de Mejia. 2004. $\beta$-carotene and lutein in forage and bovine adipose tissue in two tropical regions of Mexico. Anim. Feed Sci. Technol. 113:183-190.

Robelin, J., J. Agabriel, C. Malterre, and J. Bonnemaire. 1990. Changes in body composition of mature dry cows of Holstein, 
Limousin and Charolais breeds during fattening. I. Skeleton, muscles, fatty tissues and offal. Livest. Prod. Sci. 25:199-215.

Robelin, J., and Y. Geay. 1975. Estimation de la composition de la carcasse de taurillons à partir de la composition de la sixième côte. Bull. Tech. CRZV Theix-INRA 22:41-44.

SAS Institute. 1996. SAS/STAT User's Guide. SAS Institute Inc., Cary, NC.

Scislowski, V., D. Bauchart, P. M. Laplaud, and D. Durand. 2005. Effects of dietary n-6 or n-3 polyunsaturated fatty acids protected or not against ruminal hydrogenation on plasma lipids and their susceptibility to peroxydation in fattening steers. J. Anim. Sci. 83:2162-2174.

Strachan, D. B., A. Yang, and R. D. Dillon. 1993. Effect of grain feeding on fat colour and other carcass characteristics in previously grassfed Bos indicus steers. Aust. J. Exp. Agric. 33:269-273.

Sukhija, S. P., and D. L. Palmquist. 1988. Rapid method for determination of total fatty acid content and composition of feedstuffs and feces. J. Agric. Food Chem. 36:1202-1206.
Surai, P. F. 2002. Antioxidant protection in the intestine: a good beginning is half the battle. Pages $301-321$ in Nutritional Biotechnology in the Feed and Food Industries. T. P. Lyons and K. A. Jacques, ed. Nottingham University Press, Nottingham, UK.

Tomlinson, J. E., G. E. Mitchell, N. W. Bradley, R. E. Tucker, J. A. Bowling, and G. T. Schelling. 1974. Transfer of vitamin A from bovine liver to milk. J. Anim. Sci. 39:813-817.

Van Soest, P. J., J. B. Robertson, and B. A. Lewis. 1991. Methods for dietary fiber, neutral detergent fiber, and non starch polysaccharides in relation to animal nutrition. J. Dairy Sci. 74:35833597.

Vernon, R. G. 1986. The growth and metabolism of adipocytes. Pages 67-83 in Control and Manipulation of Animal Growth. Proc. 43rd Nottingham Easter School in Agricultural Science. Butterworths, London, UK.

Yang, A., T. W. Larsen, and R. K. Tume. 1992. Carotenoid and retinol concentrations in serum, adipose tissue and liver and carotenoid transport in sheep, goats and cattle. Aust. J. Agric. Res. 43:1809-1817. 